\title{
Yersinia pseudotuberculosis induces transcytosis of nanoparticles across human intestinal villus epithelium via invasin-dependent macropinocytosis
}

\author{
Eva GE Ragnarsson ${ }^{1, *}$, Ida Schoultz ${ }^{2, *}$, Elisabet Gullberg ${ }^{1,2}$, Anders H Carlsson², Farideh Tafazoli ${ }^{3}$, Maria Lerm³ \\ Karl-Eric Magnusson ${ }^{3}$, Johan D Söderholm² and Per Artursson ${ }^{1}$
}

Crohn's disease is characterized by a defect in intestinal barrier function, where bacteria are considered the most important inflammation-driving factor. Enteric bacteria, including $E$. coli and Yersinia spp, affect tight junctions in enterocytes, but little is known about bacterial effects on the transcellular pathway. Our objective was to study the short-term effects of $Y$. pseudotuberculosis on uptake of nanoparticles across human villus epithelium. Monolayers of human colon epitheliumderived Caco-2 cells and biopsies of normal human ileum were studied after $2 \mathrm{~h}$ exposure to $Y$. pseudotuberculosis expressing (inv +) or lacking (inv-) the bacterial adhesion molecule, invasin. Transepithelial transport of fluorescent nanoparticles (markers of transcytosis) was quantified by flow cytometry, and mechanisms explored by using inhibitors of endocytosis. Epithelial expressions of $\beta 1$-integrin and particle uptake pathways were studied by confocal microscopy. The paracellular pathway was assessed by electrical resistance (TER), mannitol flux, and expression of tight junction proteins occludin and caludin-4 by confocal microscopy. Inv + Y. pseudotuberculosis adhered to the apical surface of epithelial cells and induced transcytosis of exogenous nanoparticles across Caco-2 monolayers (30-fold increase, $P<0.01$ ) and ileal mucosa ( $268 \pm 47 \%$ of control; $P<0.01$ ), whereas inv - bacteria had no effect on transcytosis. The transcytosis was concentration-, particle size- and temperature-dependent, and possibly mediated via macropinocytosis. $Y$. pseudotuberculosis also induced apical expression of $\beta 1$-integrin on epithelial cells. A slight drop in TER was seen after exposure to inv + $Y$. pseudotuberculosis, whereas mannitol flux and tight junction protein expression was unchanged. In summary, $Y$. pseudotuberculosis induced apical expression of $\beta 1$-integrin and stimulated uptake of nanoparticles via invasindependent transcytosis in human intestinal epithelium. Our findings suggest that bacterial factors may initiate transcytosis of luminal exogenous particles across human ileal mucosa, thus presenting a novel mechanism of intestinal barrier dysfunction.

Laboratory Investigation (2008) 88, 1215-1226; doi:10.1038/labinvest.2008.86; published online 22 September 2008

KEYWORDS: barrier function; $\beta 1$-integrin; Caco-2 cells; confocal microscopy; Crohn's disease; Ussing chambers

Accumulating evidence demonstrates that genetic, environmental and immunological factors contribute to the pathogenesis of Crohn's disease (CD). ${ }^{1}$ Enteric bacteria have been proposed as the most important inflammation-driving environmental factor in inflammatory bowel disease (IBD) $)^{2-4}$ including $\mathrm{CD}$, and the link between bacterial components and $\mathrm{CD}$ has lent strong support from the discoveries of disease-promoting gene polymorphisms in components of innate immunity toward bacteria, eg, $\mathrm{NOD}^{5,6}$ and
ATG16L1. ${ }^{7,8}$ Patients with CD demonstrate defect barrier function, with a combined increase in paracellular permeability, $^{9,10}$ transcellular uptake of antigens ${ }^{11,12}$ and augmented mucosal immune responses to antigens and bacteria. ${ }^{13,14}$ It is therefore recognized that barrier function and immune responsiveness to environmental antigens are important in the disease process. ${ }^{1,15-17}$

The mechanisms that link enteric bacteria and barrier function in the initiating steps of intestinal inflammation

\footnotetext{
${ }^{1}$ Department of Pharmacy, Uppsala University, Uppsala, Sweden; ${ }^{2}$ Division of Surgery, Department of Clinical and Experimental Medicine, Linköping University, Linköping, Sweden and ${ }^{3}$ Division of Medical Microbiology, Department of Clinical and Experimental Medicine, Linköping University, Linköping, Sweden Correspondence: Professor JD Söderholm, MD, PhD, Division of Surgery, Department of Clinical and Experimental Medicine, University Hospital, SE-581 85 Linköping, Sweden. 
have in recent years been partly elucidated. For example, individuals with NOD2 alterations show increased intestinal permeability ${ }^{18}$ and alterations in secretion of the antimicrobial peptides, $\alpha$-defensins ${ }^{19}$ and DMBT1 $1{ }^{20}$ Moreover, CD-related E. coli strains can enhance the expression of CEACAM-6, which increases invasion of $E$. coli into ileal mucosa mediated by type- 1 pili-dependent adhesion. ${ }^{21}$ Other enteric bacteria that have been implicated in CD pathogenesis include Yersinia spp. Two independent groups have shown increased frequency of DNA of Y. enterocolitica and Y. pseudotuberculosis in intestinal samples of CD patients, ${ }^{22,23}$ and several case reports have linked Yersinia-induced ileitis and lymphadenitis to the early phases of clinical $\mathrm{CD}^{24,25}$ Yersinia pseudotuberculosis expresses two different virulenceassociated adhesion proteins anchored to the outer membrane, ie, invasin and YadA. Together, these two proteins mediate initial adhesion, uptake and translocation of Yersinia across the intestinal epithelium. ${ }^{26,27}$ Invasin is known to exert its effect via a high-affinity interaction with $\beta 1$-integrin, which is expressed on the luminal surface of M-cells (epithelial cell type specialized in antigen and bacterial uptake), ${ }^{28,29}$ but only on the basolateral aspect of villus epithelial cells.

We have previously shown that Y. pseudotuberculosis affects the paracellular route in model epithelia via a $\beta 1$-integrin-dependent alteration of F-actin. ${ }^{30}$ However, the effect of Yersinia spp. on the transcellular route across human intestine has not been previously addressed.

The aim of the present study was therefore to investigate whether transcytosis across human absorptive intestinal epithelium is affected by interaction with $Y$. pseudotuberculosis strains. We used YadA-deficient Y. pseudotuberculosis strains with intact invasin or lacking invasin (inv + or inv-), respectively. ${ }^{30}$ Both of the bacterial strains upregulated the apical expression of $\beta 1$-integrins on Caco-2 cells and human ileal tissues, whereas only inv $+Y$. pseudotuberculosis induced transcytosis of nanoparticles across the epithelia. Our results show for the first time that binding of invasin-expressing $Y$. pseudotuberculosis to apically localized $\beta 1$-integrins induces the uptake of nanoparticles via macropinocytosis and transcytosis across villus epithelium in human ileal tissue.

\section{MATERIALS AND METHODS Materials}

Cell culture media and supplements were purchased from Sigma Chem. Co, unless otherwise stated. The human colon carcinoma cell line, Caco-2 (clone 1, passage $x+7$ to $x+11$ ), was kindly provided by Dr Maria Rescigno (University of Milano-Bicocca, Milano, Italy $)^{31}$ and the Y. pseudotuberculosis strains by Professor Åke Forsberg (Umeå University and FOI, Umeå, Sweden). pEGFP was purchased from Clontech, Transwell polycarbonate inserts $(12 \mathrm{~mm}$ diameter, $3 \mu \mathrm{m}$ pore size) from Costar-Invitrogen and Matrigel Basement Membrane Matrix from BD Biosciences. Yellow-green and red fluorescently labeled carboxylated polystyrene particles
(FluoSpheres), Alexa Fluor-647-phalloidin and Alexa-488mouse-anti-IgG1 from Molecular Probes-Invitrogen, and the $\beta 1$-integrin antibody (clone J10) from Biogenex.

\section{Bacterial Strains and Growth Conditions}

YadA-deficient $Y$. pseudotuberculosis strains were used: (1) YpIII(pIB102) (inv +) and (2) Yp100(pIB103) (inv-). Strains were transformed with pEGFP, a plasmid carrying the gene for green fluorescent protein (GFP) and grown overnight on a rotary shaker at $26^{\circ} \mathrm{C}$ in brain heart infusion media supplemented with $5 \mathrm{mM}$ EGTA, $20 \mathrm{mM} \mathrm{MgCl}_{2}$, $100 \mu \mathrm{g} / \mathrm{ml}$ ampicillin and $50 \mu \mathrm{g} / \mathrm{ml}$ kanamycin. The overnight culture was diluted in fresh media and grown for $1 \mathrm{~h}$ at $26^{\circ} \mathrm{C}$ and $2 \mathrm{~h}$ at $37^{\circ} \mathrm{C}$. Transcription of the pEGFP plasmid was induced by addition of $100 \mu \mathrm{g} / \mathrm{ml}$ of isopropyl- $\beta$-D-1-thiogalacto-pyranoside.

\section{Cell Culture}

Caco-2 cells were grown at $37^{\circ} \mathrm{C}$ in a $10 \% \mathrm{CO}_{2}$ watersaturated atmosphere in Dulbecco's modified Eagle's medium supplemented with $10 \%(\mathrm{v} / \mathrm{v})$ fetal calf serum, $1 \%(\mathrm{v} / \mathrm{v})$ nonessential amino acids and $1 \%(\mathrm{v} / \mathrm{v})$ L-glutamine, supplemented with antibiotics (100 U/ml penicillin, $100 \mu \mathrm{g} / \mathrm{ml}$ streptomycin). Cells were seeded in Transwell inserts coated with Matrigel $\left(12 \mu \mathrm{g}\right.$ protein $\left./ \mathrm{cm}^{2}\right)$ and grown for 18-22 days. The last two days before incubation with bacteria, cell culture medium without antibiotics was used.

The cell monolayers were equilibrated in Hank's buffered salt solution (HBSS) for $20 \mathrm{~min}$ and transepithelial electrical resistance (TER) was measured at $37^{\circ} \mathrm{C}$ with a volt-ohm meter (Evohm; World Precision Instruments, Sarasota, FL, USA), before experiments, after bacterial infection and after transport studies. Monolayers with TER $<175 \Omega \mathrm{cm}^{2}$ before experiments were excluded. Integrity of monolayers was measured using $\left[{ }^{14} \mathrm{C}\right]$ mannitol, a hydrophilic paracellular marker molecule. ${ }^{32}$

\section{Bacterial Incubations}

The bacterial strains were suspended in HBSS to a final concentration of $1 \times 10^{2}, 1 \times 10^{4}$ or $1 \times 10^{6}$ bacteria/ml. The Caco- 2 cells were first exposed to bacteria for $2 \mathrm{~h}$ at $37^{\circ} \mathrm{C}$. To determine the number of intracellular bacteria, a gentamicin protection assays was performed as described earlier. ${ }^{28}$ Briefly, cultures were washed with PBS and incubated for $1 \mathrm{~h}$ in the presence of gentamicin $(100 \mu \mathrm{g} / \mathrm{ml})$ to kill remaining extracellular bacteria. Cells were lysed with $1 \%$ Triton X-100 in PBS, and intracellular viable bacteria assessed by plating serial 10 -fold dilutions on plates with kanamycin $(50 \mu \mathrm{g} / \mathrm{ml})$ and ampicillin $(100 \mu \mathrm{g} / \mathrm{ml})$.

Bacterial translocation across Caco-2 cells monolayers was determined by plating basolateral samples as above. Plates were incubated for $48 \mathrm{~h}$ at $26^{\circ} \mathrm{C}$ before counting of colony forming units (CFU). 


\section{Confocal Microscopy Studies}

After exposure to bacteria, cell monolayers and tissues, respectively, were incubated with red-fluorescent $200-\mathrm{nm}$ particles for $45 \mathrm{~min}$, washed in cold HBSS and fixed for $20 \mathrm{~min}$ with $2 \%$ formaldehyde in PBS, pH 7.4. F-actin was stained by AlexaFluor-647-phalloidin. For studies in monolayers of $\beta 1$-integrin, claudin 4 and occludin expression, filters were fixed after the exposure to bacteria. Samples were boiled for $10 \mathrm{~min}$ in $10 \mathrm{mM}$ citrate, $\mathrm{pH} 6$ ( $\beta 1$-integrin, claudin 4 ) to unmask antigenic epitopes, cooled and rinsed in distilled water. All monolayers were then permeabilized with $0.2 \%$ Triton-X-100 for $5 \mathrm{~min}$. After blocking with $1 \%$ bovine serum albumin (BSA), samples were stained with mouse anti- $\beta 1$-integrin $(500 \mu \mathrm{g} / \mathrm{ml})$, anti-claudin $4(3 \mu \mathrm{g} / \mathrm{ml})$ or anti-occludin $(10 \mu \mathrm{g} / \mathrm{ml})$ for $2 \mathrm{~h}$ at room temperature and incubated with goat-anti-mouse or goat-anti-rabbit IgG1 antibodies conjugated to Alexa 488 for $1 \mathrm{~h}$ at room temperature. Samples incubated with isotype- and concentration-matched primary antibody were used as negative controls. The cell monolayers were then mounted in Fluoromount-G (SouthernBiotech). For studies of $\beta 1$-integrin, claudin 4 and occludin expression in ileal tissue, samples were fixed in $4 \%$ formalin and mounted in Cryomount. Cryosections $(10 \mu \mathrm{m})$ were cut using a microtome (Leica, Wetzlar, Germany) and dried at room temperature on glass slides overnight. Cryosections were then immersed in boiling citrate buffer $(10 \mathrm{mM}$, pH 6) for $40 \mathrm{~min}$ ( $\beta 1$-integrin, claudin-4) or incubated with protease solution for $10 \mathrm{~min}$ at $37^{\circ} \mathrm{C}$ (occludin), as recommended by the manufacturers of the antibodies. After cooling to room temperature, the sections were rinsed several times in PBS. Cryosections were then blocked in PBS containing $5 \%$ BSA and stained with anti- $\beta 1$-integrin $(500 \mu \mathrm{g} / \mathrm{ml})$ for $2 \mathrm{~h}$ at room temperature, anti-claudin $4(3 \mu \mathrm{g} / \mathrm{ml})$ or antioccludin $(10 \mu \mathrm{g} / \mathrm{ml})$ for $1 \mathrm{~h}$ at room temperature. The primary antibodies were detected with secondary goat-anti-mouse or goat-anti-rabbit IgG1 antibodies conjugated to Alexa 488. Monolayers and cryosections were then examined using confocal laser scanning microscopy (BioRad Radiance 2000 MP with LaserSharp 2000 software). The $\beta 1$-integrin staining was quantified by measuring the mean intensity in a defined area in the apical part of the epithelial cells (apical to the nucleus) across multiple sections of the specimens.

\section{Particle Transport Across Caco-2 Cell Monolayers}

Cell monolayers were exposed to Y. pseudotuberculosis inv + and inv- strains in a concentration of $1 \times 10^{6} \mathrm{CFU} / \mathrm{ml}$, for $2 \mathrm{~h}$ before addition of nanoparicles. The particle transport was studied at 37,20 and $4^{\circ} \mathrm{C}$, respectively, in HBSS supplemented with $1 \%$ FCS. A solution of yellow-green fluorescent particles ( 200 or $500 \mathrm{~nm}$ ) was added apically at a final concentration of $2.5 \times 10^{9}$ particles $/ \mathrm{ml}$, and samples drawn basolaterally at regular intervals to monitor particle transport. The amount of transported particles was quantified by flow cytometry (FACScan, BD and Cytomics FC500 MPL, BeckmanCoulter). To determine the pathway involved in the nanoparticle, transport cells were incubated with the following substances after exposure to bacteria. 5-( $N$-ethyl$N$-isopropyl) amiloride (EIPA; $50 \mu \mathrm{g} / \mathrm{ml}$ ) was used as an inhibitor of macropinocytosis. Chlorpromazine $(60 \mu \mathrm{mol} / \mathrm{ml})$ and methyl- $\beta$-cyclodextrin $(2.5 \mathrm{mmol} / \mathrm{ml})$ were used as inhibitors of clathrin-mediated endocytosis and caveolar endocytosis, respectively. Nystatin $(50 \mu \mathrm{g} / \mathrm{ml})$ was used as an inhibitor of lipid-rafts mediated endocytosis, including caveolae and macropinocytosis. Cell monolayers were preincubated for $20 \mathrm{~min}$ with each specific inhibitor before particles were added to the monolayers. Inhibitors were added to the apical and basolateral side and were present during the whole experiment.

\section{Particle Transport across Human lleum after Exposure to Bacteria}

Human ileum biopsies were obtained during routine colonoscopy follow-up after local treatment for colonic polyps in six otherwise healthy patients (four men, two women; age range 45-66 years), as approved by the Regional Committee of Human Ethics in Linköping. The human tissues were immediately transported to the laboratory in ice-cold oxygenated Krebs buffer, $\mathrm{pH}$ 7.4, examined under dissection microscope to assure that only tissue without areas of follicleassociated epithelia (FAE) were studied, ${ }^{33}$ and mounted in modified Ussing chambers ${ }^{34}$ (Harvard Apparatus Inc.). The mucosal compartments were filled with $10 \mathrm{mM}$ mannitol in Krebs buffer, whereas $10 \mathrm{mM}$ glucose was used in the serosal compartment. Both sides were continuously oxygenated with $95 \% \mathrm{O}_{2} / 5 \% \mathrm{CO}_{2}$ and circulated by gas flow. Transmucosal potential difference (PD), short circuit current and electrical resistance were assessed using two pairs of electrodes $(\mathrm{Ag} / \mathrm{AgCl}$ with agar-salt bridges and platinum electrodes, respectively) for assessment of tissue viability as previously described. $^{33,35}$ Before transport experiments chambers were equilibrated for $20 \mathrm{~min}$ to achieve steady-state conditions in PD. Live Y. pseudotuberculosis (inv + or inv-) were added to the mucosal side at a final concentration of $1 \times 10^{8} \mathrm{CFU} / \mathrm{ml}$. After two hours, the bacterial suspension was removed and replaced with red fluorescent $200 \mathrm{~nm}$ particles at a final

\begin{tabular}{lccc}
$\begin{array}{l}\text { Table } 1 \text { Transepithelial resistance during transport } \\
\text { experiment }\end{array}$ \\
\hline Time $(h)^{\text {a }}$ & 0 & 2 & 4 \\
\hline Control $(n=136)$ & $276 \pm 42$ & $290 \pm 52$ & $257 \pm 46$ \\
Inv+ $(n=137)$ & $273 \pm 38$ & $263 \pm 42$ & $191 \pm 40^{*}$ \\
Inv $-(n=13)$ & $244 \pm 27$ & $246 \pm 36$ & $228 \pm 38$
\end{tabular}

${ }^{\mathrm{a}}$ The integrity of the cells was controlled three times during the experiments: at the beginning $(t=0 \mathrm{~h})$, after bacterial exposure $(t=2 \mathrm{~h})$ and after particle exposure at the end of the experiment $(t=4 \mathrm{~h})$. Values are expressed in $\Omega \mathrm{cm}^{2}$ (average \pm s.d.).

${ }^{\star} P<0.05$ as compared to controls. 


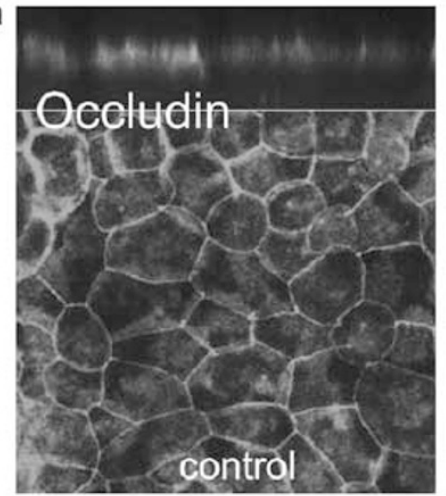

b

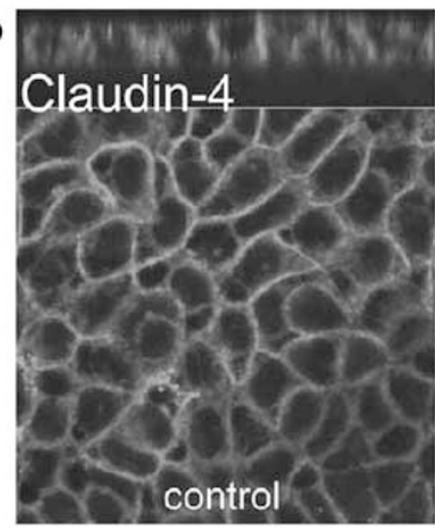

c

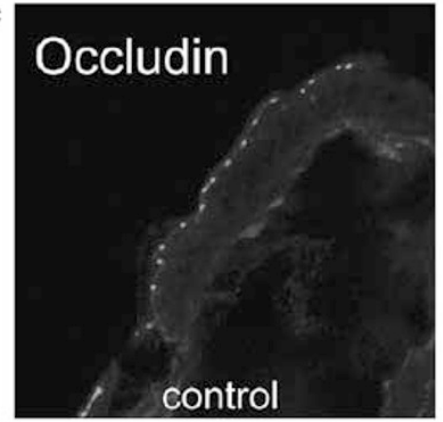

d

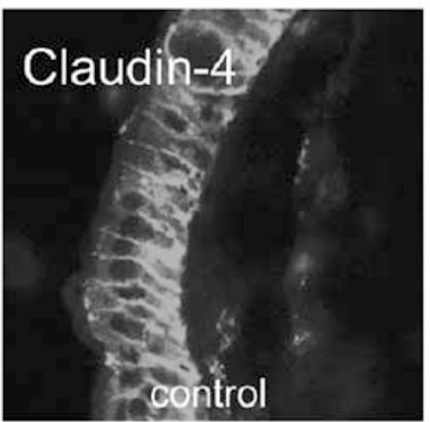

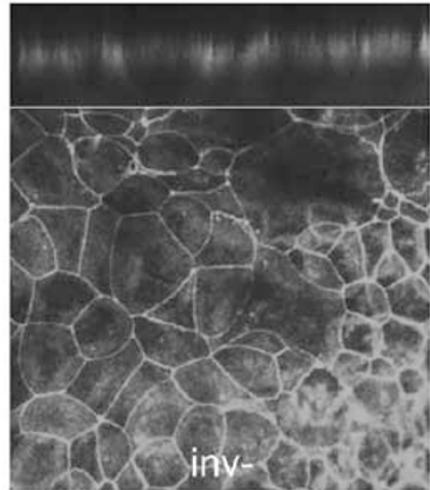
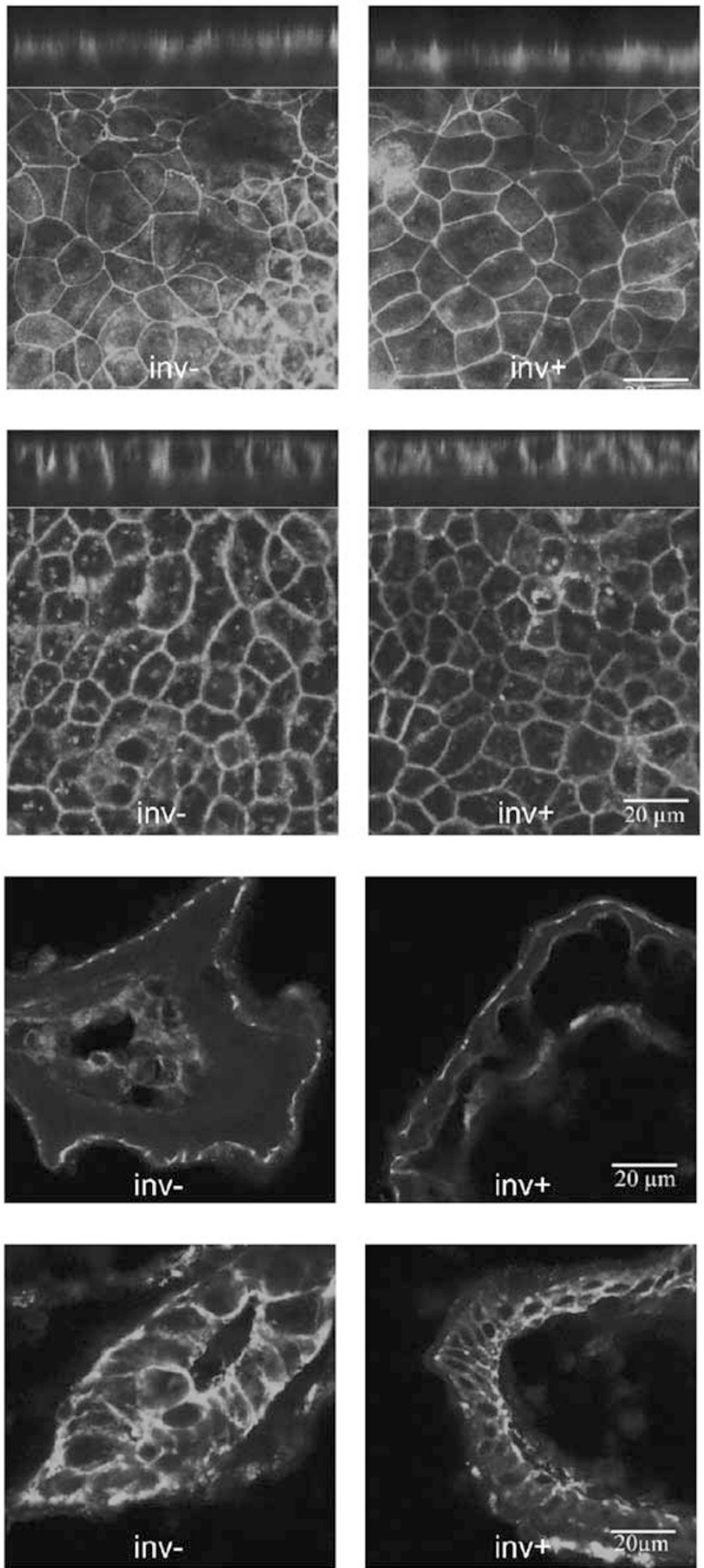

Figure 1 Expression of tight junction proteins, occludin and claudin 4 in cell monolayers and ileal tissue after $2 \mathrm{~h}$ exposure to $Y$. pseudotuberculosis inv + and inv-, respectively. Monolayers and tissue not exposed to bacteria were used as controls. (a) Digitally acquired XZ stack sections (upper panel) and optical XY cross sections (lower panel) of Caco-2 monolayers, showing expression of occludin in controls (left panel) and after exposure to inv- (middle panel) and inv + (right panel). (b) Digitally acquired XZ stack sections (upper panel) and optical XY cross sections (lower panel) of Caco-2 monolayers, showing expression of claudin 4 in controls (left panel) and after exposure to inv- (middle panel) and inv + (right panel). (c) Expression of occludin in optical cross sections of ileal tissue, controls (left panel), after exposure of inv- (middle panel) and inv + (right panel). (d) Expression of claudin 4 in optical cross sections of ileal tissue, controls (left panel), after exposure of inv - (middle panel) and inv + (right panel). $(\times 63$ objective, $\times 2$ zoom.) 
concentration of $2.5 \times 10^{9}$ particles $/ \mathrm{ml}$. Background particle transport was determined in tissues that were not exposed to bacteria. Translocation of particles was measured after additional $2 \mathrm{~h}$, by analyzing the serosal buffer in a Varian Eclipse $^{\mathrm{TM}}$ fluorescence reader at $580 / 620 \mathrm{~nm}$. In a second set of experiments, EIPA $(100 \mu \mathrm{M})$ was added to the serosal side, after exposure to inv $+Y$. pseudotuberculosis. After $20 \mathrm{~min}$ incubation, particles were added, samples withdrawn after $2 \mathrm{~h}$, and translocation of particles analyzed as described above.

\section{Statistics}

Particle transport is expressed as mean \pm s.e.m. The differences between treated groups were analyzed using nonparametric one-tailed Mann-Whitney tests. Bacterial internalization was evaluated with one-way analysis of variance in combination with Bonferroni's multiple comparison tests.

\section{RESULTS}

\section{Cell Monolayer and Tissue Integrity}

Previous studies in our laboratory have shown that TER values above $175 \Omega \mathrm{cm}^{2}$ represents an intact barrier function of the cell monolayer. ${ }^{36,37}$ In agreement with this the cell monolayers expressed TER values within the given range during the experiment. Similarly, the excised ileal human tissue maintained viability during the experiment as confirmed by a starting PD of at least $-0.2 \mathrm{mV}$ and a PD that remained at a level of $>75 \%$ of initial value. ${ }^{35,37}$ Thus, neither the bacteria nor the nanoparticles affected the integrity of the cell monolayers or the tissue.

\section{Paracellular Pathway}

Following $2 \mathrm{~h}$ of incubation with the $Y$. pseudotuberculosis (inv- or inv + ) at concentrations of $1 \times 10^{6}$ bacteria/ml, followed by $2 \mathrm{~h}$ of exposure to nanoparticles, a small decrease in TER was observed for the inv + exposed cells compared to unexposed controls (Table 1). The transport of mannitol, a marker commonly used for paracellular transport, however did not change significantly during the bacterial incubation $\left(6.7 \times 10^{-7} \pm 1.4 \times 10^{-7} \mathrm{~cm} / \mathrm{s}^{7}\right.$ as compared to controls $\left(6.0 \times 10^{-7} \pm 0.65 \times 10^{-7} \mathrm{~cm} / \mathrm{s}^{7}\right)$.

To further elucidate the effects of inv- or inv + Y. pseudotuberculosis on the paracellular pathway, the expression of tight junction proteins occludin and claudin 4 were studied. (Figure 1a-d). As shown by confocal microscopy occludin remained at the junctional complex after infection with the two $Y$. pseudotuberculosis strains in human ileal tissue as well as in monolayers. Similarly, distribution of claudin 4 at the lateral cell margins remained equal to the control after infection with bacteria, showing that the staining pattern of these tight junction proteins did not change during the $2 \mathrm{~h}$ incubation with bacteria.

\section{Localization of $Y$. pseudotuberculosis and Nanoparticles in Caco-2 Cell Monolayers and Intestinal Villus Tissue}

The localization of the GFP-expressing inv + and invY. pseudotuberculosis and the red-fluorescent nanoparticles in the cell monolayers (Figure 2) and in the ileal tissues (Figure 3) a

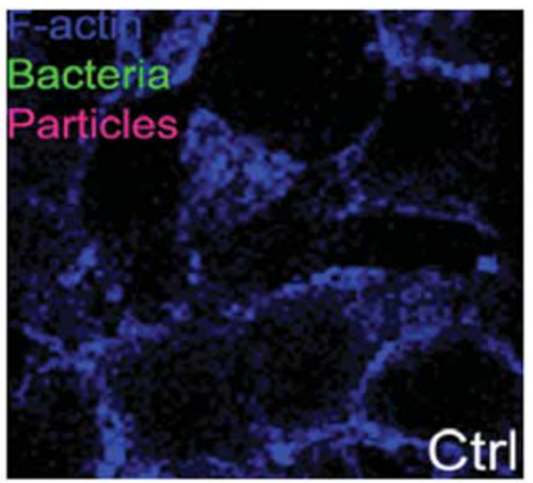

b

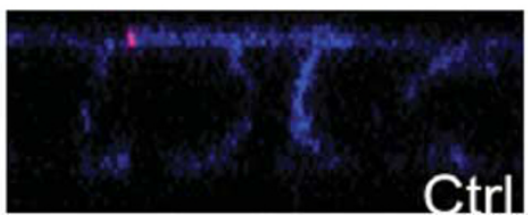

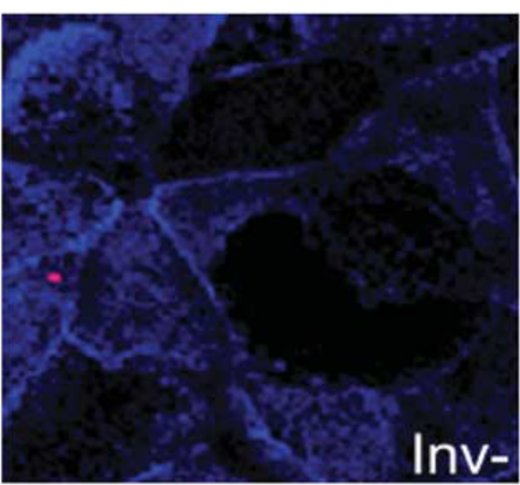
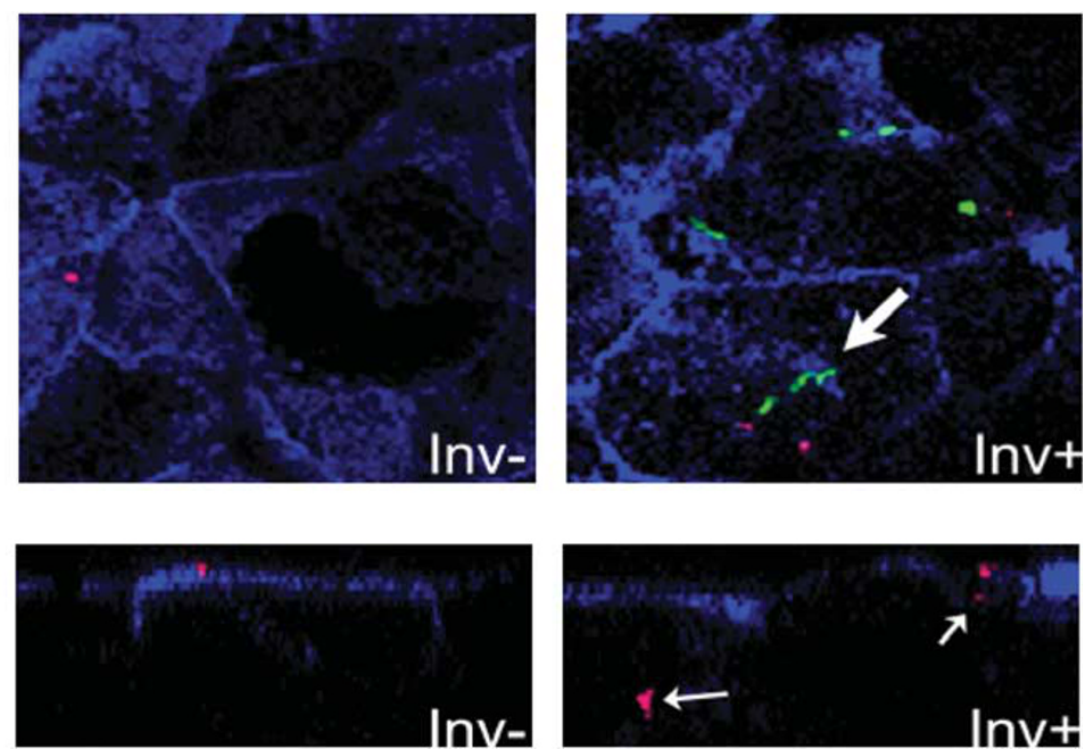

Figure 2 Visualization of $Y$. pseudotuberculosis and particles in Caco-2 cell monolayers. Cells were exposed to bacteria during $2 \mathrm{~h}$. Particles were added and after $45 \mathrm{~min}$ the cells were rinsed and fixed. The Caco-2 cells were stained for F-actin (blue), the bacteria were identified by their GFP-expressing properties (green) and the particles by their fluorescent label (red). (a) Apical images and (b) optical cross sections of the Caco- 2 cell monolayers. In the unexposed (Control) monolayers and inv - exposed cells no attached bacteria and only small numbers of particles were seen on the apical surface of the cells, whereas in the inv + -exposed cell monolayers both attached bacteria (large arrows) and surface-bound and internalized particles (small arrows) were found ( $\times 63$ objective, $\times 3$ zoom). 

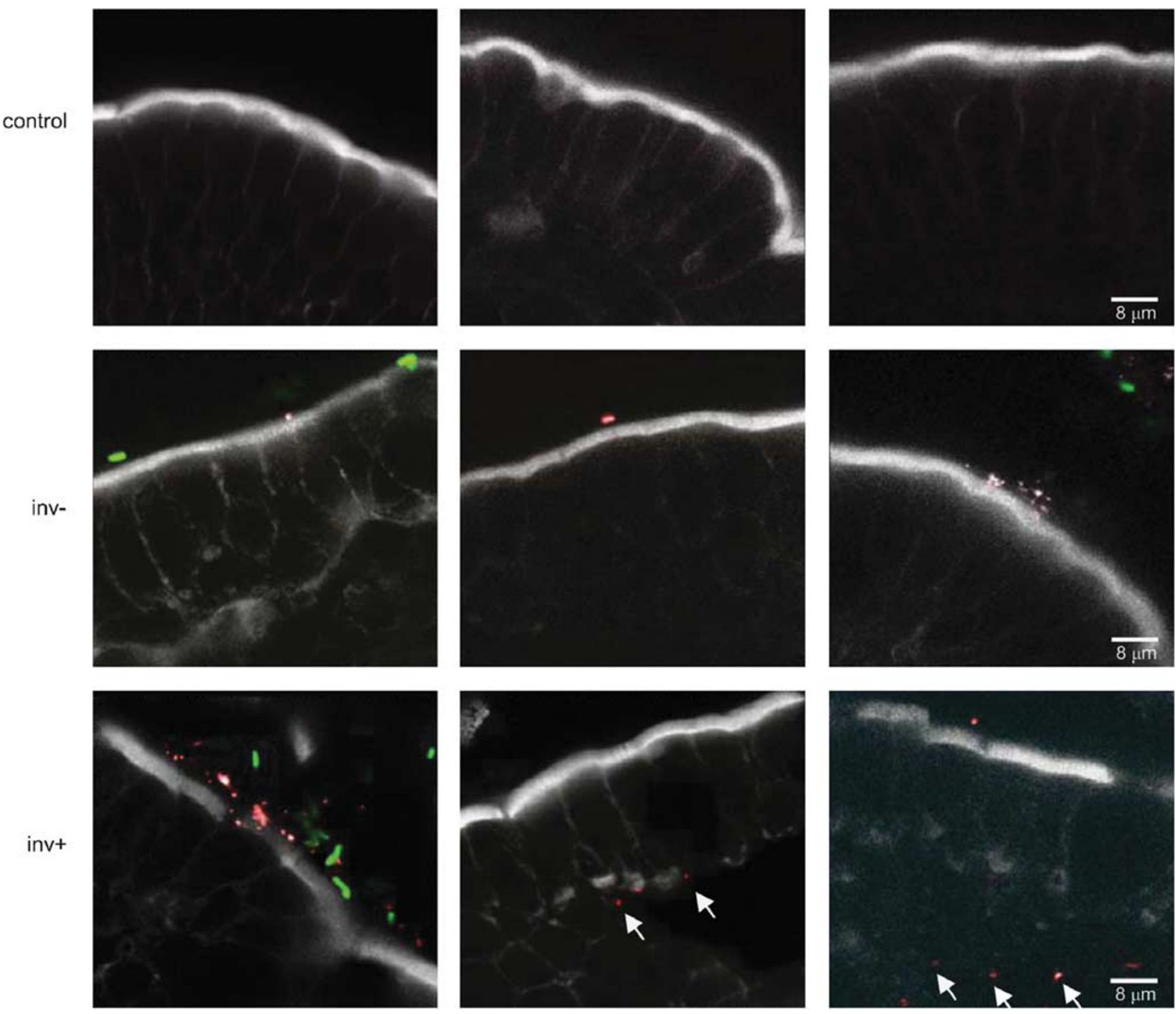

Figure 3 Visualization of $Y$. pseudotuberculosis and particles in human intestinal villus epithelium. lleal mucosal tissues were mounted in Ussing chambers and exposed to bacteria during $2 \mathrm{~h}$. Particles were added and after $45 \mathrm{~min}$ tissues were rinsed and fixed. White $=\mathrm{F}$-actin, green $=Y$. pseudotuberculosis, red $=$ nanoparticles $(\times 63$ objective, $\times 4$ zoom). Internalized particles (small arrows) were found only in tissues exposed to inv $+Y$. pseudotuberculosis.

were investigated by confocal microscopy. Only inv $+Y$. pseudotuberculosis remained adherent to the cell monolayers after washing, suggesting that invasin was needed for binding to the cell surface (Figure 2a, right panel). Optical crosssections revealed a very small number of bacteria inside or on the basolateral side of the cells. The nanoparticles were found inside the cell monolayers exposed to inv $+Y$. pseudotuberculosis (Figure 2b, right panel) and could not be observed between the cells. However, no particle uptake or transport could be identified in untreated monolayers or in monolayers exposed to inv- Y. pseudotuberculosis (Figure 2a and b, middle panels). The results from the corresponding experiments in excised human ileal tissues (Figure 3) were similar to those obtained with the monolayers. Ileal mucosa exposed to inv + Y. pseudotuberculosis displayed significant binding of the bacteria and nanoparticles to the apical surface of epithelial cells. Nanoparticles transported across the epithelia to lamina propria were also identified, indicative of transepithelial transport (Figure 3, lower panel). In tissue exposed to inv- Y. pseudotuberculosis only a few bacteria and nanoparticles could be identified on the apical cell surface (Figure 3 , middle panel), whereas no attached or transcytosed nanoparticles were found in the untreated tissues (Figure 3, upper panel).

\section{Quantification of Nanoparticle Transport across Caco-2 Monolayers and Human Ileum}

The number of fluorescent nanoparticles transported by the Caco-2 monolayers gradually increased with the number of inv + Y. pseudotuberculosis $\left(10^{2}, 10^{4}\right.$ or $10^{6}$ bacteria $/ \mathrm{ml}$; 
Figure 4a). The largest amount of transported nanoparticles was obtained after exposure to the $10^{6}$ bacteria/ml concentration, which was used in the subsequent experiments. After exposure to inv- Y. pseudotuberculosis, only a very small transepithelial transport of nanoparticles was observed, supporting the notion that the induction of nanoparticle transport required invasin (Figure $4 \mathrm{~b}$ ). The results obtained in Caco-2 cells were further confirmed in ileal tissues. Exposure to inv $+Y$. pseudotuberculosis resulted in a significant increase in particle translocation (to $268 \pm 47 \%$ of control), whereas inv- did not (Figure 4c).

\section{Invasin-Induced Particle Transport is Size and Temperature Dependent}

The effect of inv $+Y$. pseudotuberculosis exposure on nanoparticle transport was dependent on the size of the particles. Although the increase in the number of transported particles was 77 -fold for the $200 \mathrm{~nm}$ particles, the number of transported nanoparticles having a diameter of $500 \mathrm{~nm}$ increased only 12 -fold (Figure $4 \mathrm{~d}$ ). However, when recalculated to the transported volume, the total volume of the transported $500 \mathrm{~nm}$ particles was fourfold higher than the volume transported by the $200 \mathrm{~nm}$ particles.

In order to elucidate whether the particle transport induced by inv $+Y$. pseudotuberculosis was mediated by an energy-dependent process we investigated the transport at 4 and $20^{\circ} \mathrm{C}$. At $4{ }^{\circ} \mathrm{C}$, the transport was only $7 \%$ of the transport occurring at $37^{\circ} \mathrm{C}$ at $120 \mathrm{~min}$ and similar to the unexposed controls. The same pattern could also be observed at $20^{\circ} \mathrm{C}$, where transport decreased by $50 \%$ suggesting that the nanoparticle transport required an energy-dependent process (data not shown).

\section{Induction of $\beta 1$-expression in Caco-2 Cells and Human lleum}

In control Caco- 2 cell monolayers, $\beta 1$-integrin expression was mainly localized to the cell borders below the tight junctions (Figure 5a), which is in agreement with the reported staining pattern in the human villus epithelium ${ }^{38}$ and MDCK cells. ${ }^{30}$ After exposure to inv $+Y$. pseudotuberculosis, the expression of $\beta 1$-integrin increased and was redistributed to the apical cell membrane (Figure $5 a$ and $b$ ). It has previously been shown that an increased expression of $\beta 1$-integrin in the apical membrane is due to increased maturation of existing precursors and hence, redistribution of the protein, rather than an elevated production of $\beta 1$-integrin. ${ }^{38,39}$ An equivalent pattern was observed after exposure to inv- Y. pseudotuberculosis (Figure 5a and b), suggesting that other factors than invasin contributed to the altered $\beta 1$-integrin expression and distribution. To assure that the interaction between $Y$. pseudotuberculosis and $\beta 1$-integrins was in agreement with previous reports, ${ }^{40}$ we investigated bacterial uptake into the Caco-2 cells, using a gentamycin protection assay. ${ }^{34}$ The results showed that inv + but not inv- bacteria were taken up to a low, but significant
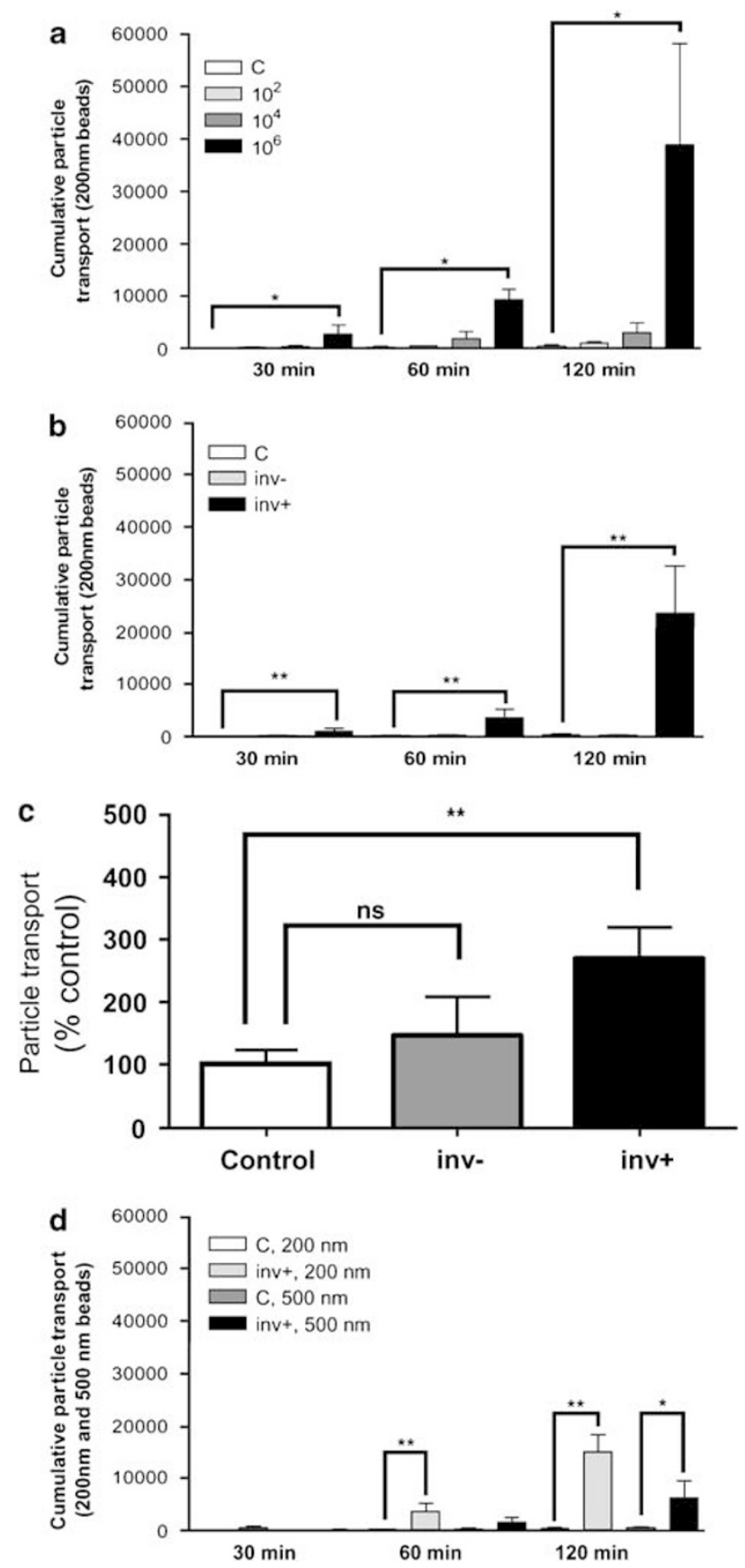

Figure 4 The transport of nanoparticles across Caco-2 monolayers and human intestinal villus epithelium was studied after $2 \mathrm{~h}$ exposure to Y. pseudotuberculosis strains expressing (inv + ) or lacking (inv-) invasin. (a) Effects of increasing concentrations inv + on $200 \mathrm{~nm}$ particle transport across cell monolayers $(n=4-5)$. (b) Effects of invasin on particle transport across Caco- 2 cells $(n=4-5)$. (c) Particle transport across human intestinal villus epithelium after exposure to inv + and inv $-Y$. pseudotuberculosis strains, respectively $(n=3-4)$. (d) Cell monolayers were exposed to inv + and the transport of $200 \mathrm{~nm}$ and $500 \mathrm{~nm}$ particles was studied across Caco- 2 cells $(n=3-4)$. Statistically significant differences are indicated by ${ }^{*} P<0.05$ and ${ }^{*} P<0.01$.

extent, comparable to that reported previously (Table 2). These results confirm that there is a functional invasin-dependent internalization of the bacteria in Caco-2 cells. No transport of 
a

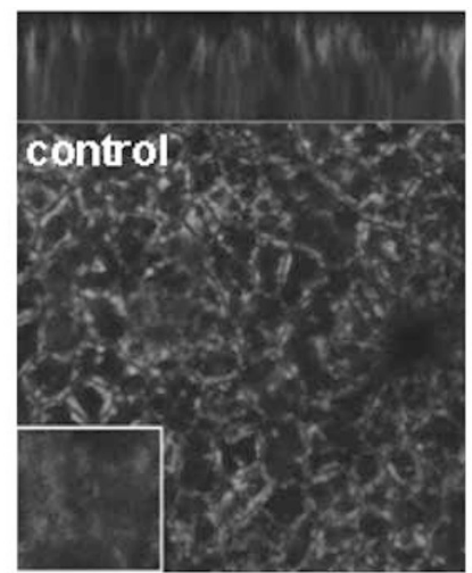

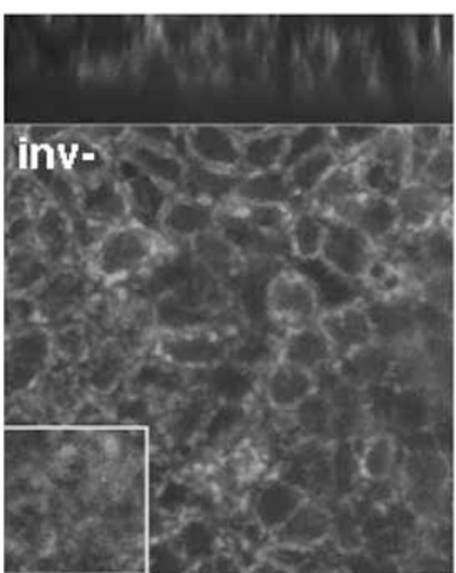

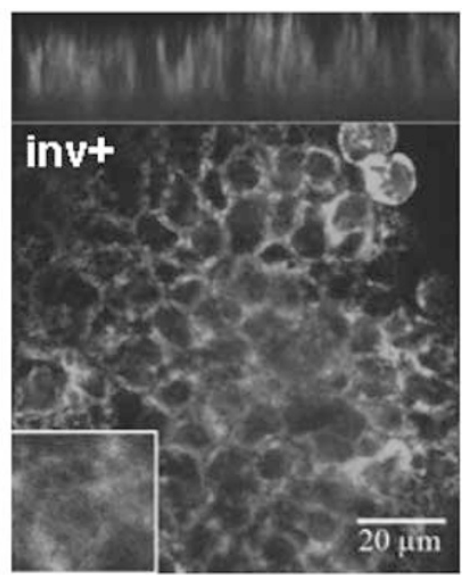

b

Fluorescence intensity Caco-2
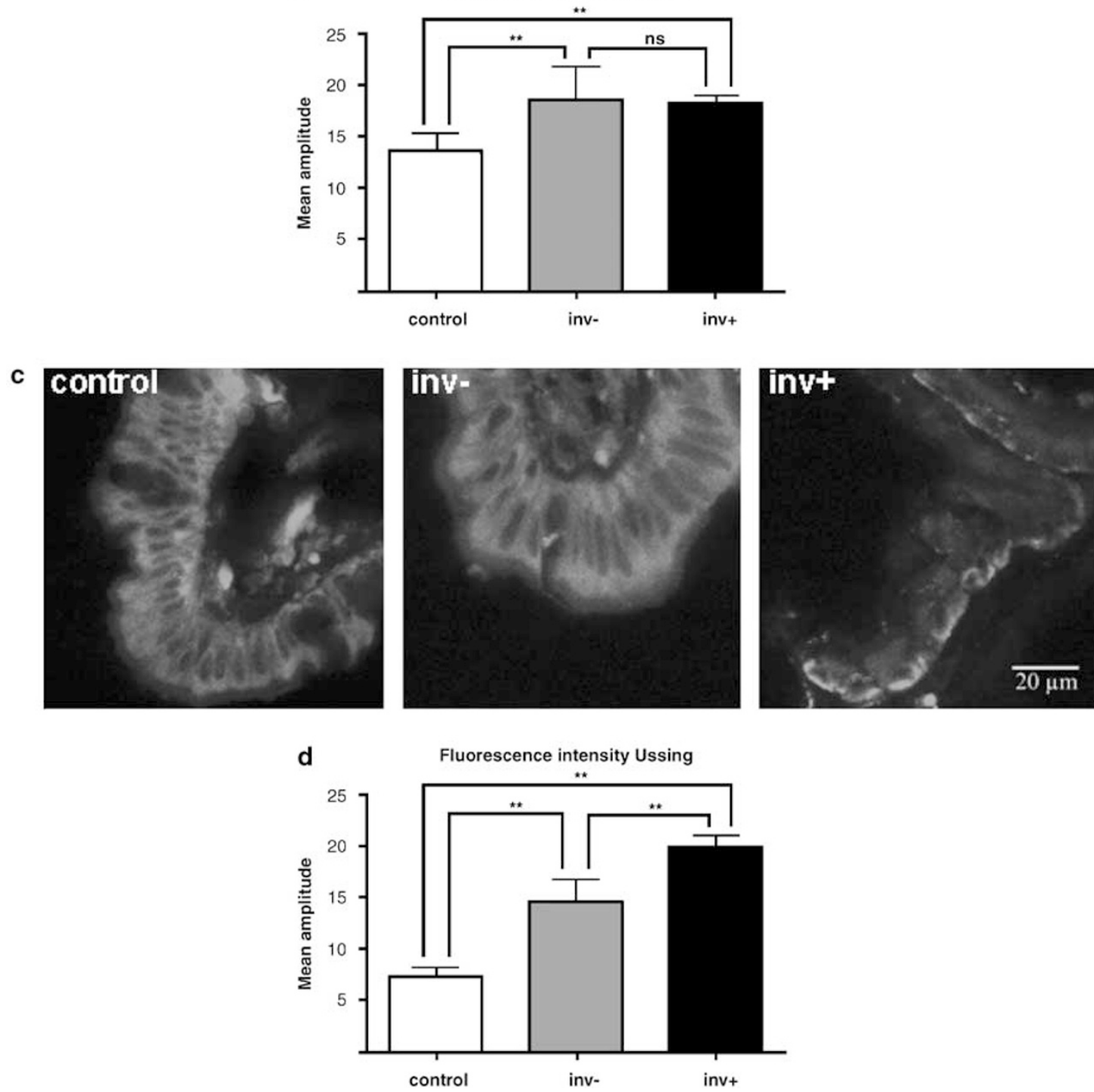
bacteria across the Caco-2 cell monolayers was however observed during the 2-h incubation period (data not shown).

In human ileal tissue a more pronounced increase in expression and apical redistribution of $\beta 1$-integrin could also be observed after exposure to inv $+Y$. pseudotuberculosis (Figure $5 c$ and $d$ ). A qualitative difference between the redistribution induced by the inv + and inv- bacteria was also detected. Although staining of tissue exposed to inv$Y$. pseudotuberculosis showed a more even distribution of $\beta 1$-integrin in the epithelial cells in a pattern similar to the control tissue (Figure 5c), exposure to inv + Y. pseudotuberculosis generated a strong uniform staining of $\beta 1$-integrin at the apical aspect of the epithelial cells.

\section{Invasin-dependent Particle Transport Reduced by Endocytosis Inhibitors}

The transport of nanoparticles in monolayers exposed to inv + Y. pseudotuberculosis was investigated, as previously described, after incubation with chlorpromazine, methyl$\beta$-cyclodextrin, nystatin and EIPA. Chlorpromazine, known to function as a calmodulin-antagonist and most commonly used as a inhibitor of clathrin-mediated endocytosis, ${ }^{40}$ reduced the transport of particles significantly and the inhibition was nearly $100 \%$ compared to the transport occurring at $37^{\circ} \mathrm{C}$ after exposure of inv $+Y$. pseudotuberculosis. Methyl- $\beta$-cyclodextrin and Nystatin deplete cholesterol from the plasma membrane and are used as inhibitors of caveolae and macropinocystosis, ${ }^{42,43}$ and had an almost equal inhibitory effect on the particle transport in Caco-2 cells (Table 3). Similarly, EIPA used as a selective inhibitor of macropinocytosis ${ }^{41-43}$ decreased the transport to the same extent and inhibition was $80 \%$ of the inv + values (Figure 6). Together these data support that the inv + Y. pseudotuberculosis induced transport of particles are primarily mediated by macropinocytosis. In agreement with this, the nanoparticle transport was reduced in ileal tissue to $32 \%$ of inv + in the presence of EIPA (Figure 6).

\section{DISCUSSION}

Previous studies using other models and longer times of exposure have shown that $Y$. pseudotuberculosis affects the paracellular route in model epithelia. To our knowledge, we are here the first to show that short-term exposure to the enteroinvasive bacteria $Y$. pseudotuberculosis can induce a substantial increase in transcytosis of nanoparticles in intestinal villus epithelium, whereas the paracellular pathway was only modestly affected during these experimental conditions. Earlier in vitro studies have demonstrated a transformation of epithelial phenotype to M cell-like cells in Caco2 cells co-cultured with lymphocytes isolated from Peyer's patches or with Raji B cells. ${ }^{37,45}$ We have also shown that human FAE has a very high capacity for uptake of nanoparticles and bacteria compared with villus epithelium. ${ }^{33,36}$ Moreover, previous in vivo studies in rodents demonstrated an increased transcytosis across FAE after microbial challenge, explained either by induction of the $\mathrm{M}$ cell phenotype and/or an increased transport rate in already present $\mathrm{M}$ cells. ${ }^{46,47}$ In the present study we showed that inv + $Y$. pseudotuberculosis rapidly altered the transcytosis pattern of Caco-2 monolayers in complete absence of lymphocytes or lymphocyte-derived products. Moreover, we verified this

\section{Table 2 Internalization of viable $Y$. pseudotuberculosis by Caco-2 cells}

\begin{tabular}{lccc}
\hline Strain & $\begin{array}{c}\text { Incubation } \\
\text { time }(\mathrm{h})\end{array}$ & $\begin{array}{c}\text { No of internalized } \\
\text { bacteria }^{\mathrm{a}}\end{array}$ & Internalization (\%) \\
Inv+ & 1 & $7 \pm 6$ & 0.09 \\
Inv- & 1 & $0 \pm 0$ & 0.00 \\
Inv+ & 2 & $19 \pm 3^{\mathrm{b}}$ & 0.24 \\
Inv- & 2 & $2 \pm 2^{\mathrm{c}}$ & 0.02 \\
Control & 4 & $0 \pm 0$ & 0.00 \\
\hline
\end{tabular}

${ }^{\mathrm{a}} \mathrm{CFU} \pm$ s.e.m., $n=4$.

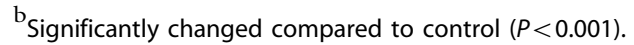

${ }^{c}$ Significantly changed compared to inv $+2 \mathrm{~h}(P<0.01)$.

Table 3 Particle trancytosis during $60 \mathrm{~min}$ in Yersinia inv+ exposed Caco-2 cells in the presence of endocytosis inhibitors

Inhibitor (concentration)

$\%$ Inhibition $^{\mathrm{a}}$

Nystatin $(50 \mu \mathrm{g} / \mathrm{ml})$

$76(* * *)$

Chlorpromazine $(60 \mu \mathrm{M})$

$99(* *)$

Methyl- $\beta$-cyclodextrin ( $2.5 \mathrm{mM}$ )

$80\left({ }^{*}\right)$

EIPA $(50 \mu \mathrm{M})$

$77(* * *)$

${ }^{\mathrm{a}}$ Values are expressed as $\%$ inhibition compared to inv+ exposed cells. ${ }^{*} P<0.05 ;{ }^{* *} P<0.01 ;{ }^{* * *} P<0.001$.

Figure 5 B1-Integrin expression and quantification in Caco-2 cells and human intestinal villus tissue. Monolayers and tissues were exposed to inv + and inv $-Y$. pseudotuberculosis during $2 \mathrm{~h}$ followed by immunofluorescence staining for $\beta 1$-integrin, the adhesion molecule for invasin. (a) Digitally acquired $\mathrm{XZ}$ stack sections of Caco-2 cell monolayers (upper panel) and optical XY cross sections (lower panel) in control (left panel), cells exposed to inv- (middle panel) and inv + (right panel). Insets in lower panels show high-power XY cross sections at the level of microvilli, corroborating the increased intensity of apical $\beta 1$-integrin expression in the XZ sections. (b) Quantification of fluorescence intensity on the Caco-2 cells; (c) Optical cross sections of human ileal tissue, showing the expression of $\beta 1$-integrin in control (left panel), and after exposure to inv- (middle panel) and inv + . (d) Quantification of fluorescence intensity of $\beta 1$-integrin expression in the apical part of the villus epithelium. Green $=\beta 1$-integrin (Alexa-488). Statistically significant differences are indicated by ${ }^{\star} P<0.05$ and ${ }^{* * P}<0.01$. 

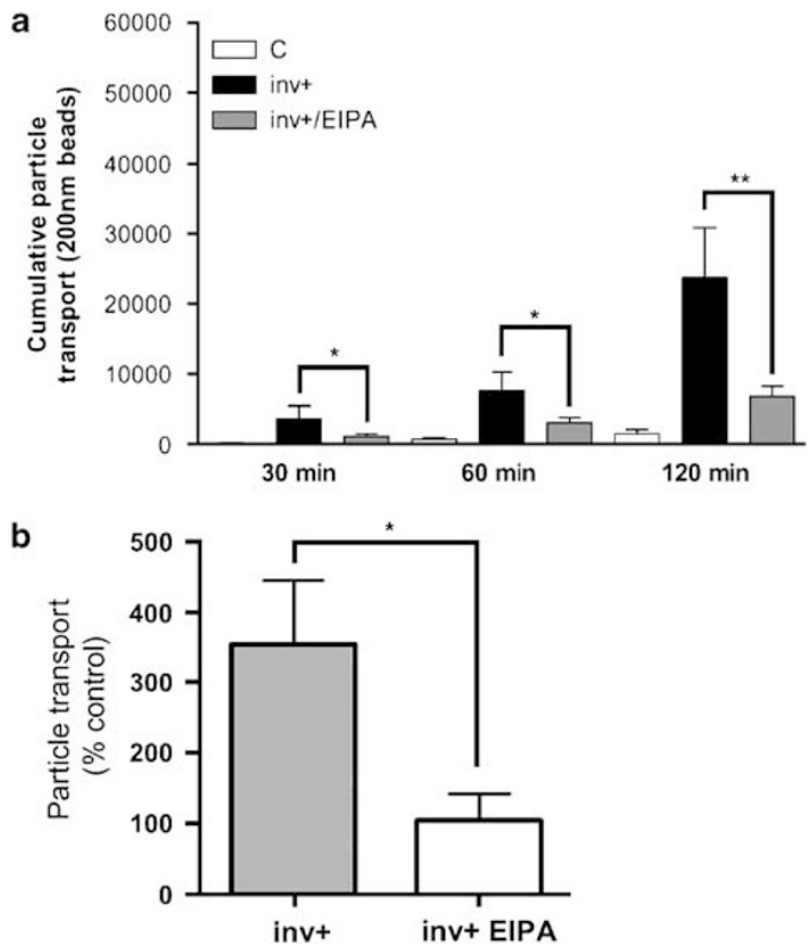

Figure 6 Particle transport across Caco-2 cells (a) and human intestinal villus epithelium (b) after $2 \mathrm{~h}$ exposure to $Y$. pseudotuberculosis inv + in the presence of the pharmacological macropinocytosis inhibitor 5-(N-ethyl$\mathrm{N}$-isopropyl) amiloride (EIPA; $50 \mathrm{am}$ ). In (a) a control group was included at each time-point to monitor batch-to-batch variations in background particle transport and in (b) tissue not exposed to bacteria were included to monitor background particle transport (control). Bars show mean values \pm s.e.m., $(n=4-6)$. Statistically significant differences are indicated by ${ }^{*} P<0.05$ and ${ }^{*} P<<0.01$.

rapidly inducible invasin-dependent transport in villus epithelium of human ileum, which implicated bacterial binding to $\beta 1$-integrins as an important step in the induction of transcytosis. Y. pseudotuberculosis induced increased expression or redistribution of $\beta 1$-integrin on Caco- 2 cells and ileal villus tissues mounted in Ussing chambers. This is intriguing, as $\beta 1$-integrins are normally not expressed on the surface of absorptive epithelial cells. ${ }^{38}$ The increase was detectible already after $2 \mathrm{~h}$ of exposure to the bacteria, which is compatible with earlier reports in rodents, where an increased number of $\mathrm{M}$ cells has been detected in ileal loops already $1 \mathrm{~h}$ after inoculation with Streptococcus pneumoniae R36a. ${ }^{47}$ Our investigation was focused on the cellular responses in nonphagocytic cells after exposure to $Y$. pseudotuberculosis, but it is possible that an increased transcytosis also can be seen after exposure to other enteroinvasive bacteria. In support of this notion, Lyons et al recently showed that Salmonella typhimurium transcytoses flagellin via a SPI2-mediated vesicular transport across polarized epithelial cells. Transcytosed flagellin then triggers the production of proinflammatory cytokines via the activation of Toll-like receptor 5, thereby contributing to the intestinal inflammation known to be caused by $S$. typhimurium. ${ }^{48}$
In agreement with what we report here, Lyons et al show that flagellin is incorporated in vesicles and trancytosed across the epithelium without being dependent on bacterial invasion. In addition, several bacterial species are known to interact with $\beta 1$-integrin $^{49}$ and some species, such as Listeria, share some common strategies for cellular uptake. ${ }^{50}$ However, it remains to be elucidated by future studies whether these have the possibility to induce transcytosis of microparticles.

The nanoparticle transport was temperature-dependent, indicating that the process required an active ATP metabolism in the cells. To further elucidate the transport mechanisms, cells were treated with different pharmacological endocytosis inhibitors. Chlorpromazine, methyl- $\beta$ cyclodextrin and nystatin all decreased the transport of nanoparticles across monolayers. Chlorpromazine is known to function as a calmodulin antagonist and has mainly been used as an inhibitor of clathrin-mediated endocytosis. ${ }^{40}$ However, calmodulin is also known to interact with several small GTPases including Rac- $1,{ }^{51}$ which is known to stimulate actin filament reorganization and membrane ruffling ${ }^{52,53}$ processes essential for macropinocytosis. Methyl- $\beta$-cyclodextrin is known to extract cholesterol from the plasma membrane and has mostly been used as an inhibitor of caveolae-mediated endocytosis. ${ }^{54}$ However, depletion of cholesterol from the plasma membrane has also been shown to inhibit the localization of activated Rac-1 to the plasma membrane, and hence the stimulation of actin filaments and membrane ruffling. ${ }^{55}$ In agreement with this treatment with methyl- $\beta$-cyclodextrin resulted in a decreased particle transport. In addition, nystatin, also known to remove cholesterol from the plasma membrane, ${ }^{42,43}$ significantly reduced particle transport across cell monolayers. Together these data suggested that the transport of particles was mediated via macropinocytosis.

Macropinocytosis is a challenging mechanism to study because no specific markers or drugs are available that interfere with this process. It is, however known that this particular pathway acquire proteins common to other endocytotic pathways and it is therefore not surprising that the above-mentioned inhibitors affects macropinocytosis as well. ${ }^{56}$ Lately, amiloride analogues have been used as selective inhibitors for this pathway. It has been suggested that amiloride, as a potent inhibitor of the plasma membrane $\mathrm{Na}^{+} / \mathrm{H}^{+}$exchange protein ${ }^{57}$ changes the intracellular $\mathrm{pH}$ and thereby induces alterations in the cytoskeleton ${ }^{58}$ or other processes related to macropinocytosis. ${ }^{59}$ To further elucidate if the Y. pseudotuberculosis inv + induced transport of particles is mediated via macropinocytosis we used EIPA as a selective inhibitor. EIPA significantly reduced the particle transport across Caco-2 cells as well as in human villus tissue.

In other words, these results propose that the inv + bacteria induced an active energy-dependent transport process, possibly via macropinocytosis, across the epithelium. Future studies will need to be focused on further elucidating the signaling pathways involved. One possibility is that 
Yersinia via injection of various Yop proteins can affect the Rho proteins, RhoA, Rac1 and Cdc42, ${ }^{52,60,61}$ that have been implicated as important regulators in the trafficking of vesicles during phagocytosis and macropinocytosis. ${ }^{52,53}$ Alternatively, inv + Yersinia (but not inv-) activate MAP-kinases, ${ }^{62}$ among them p38 MAPK, which in turn can promote endocytosis. ${ }^{63}$

The dysregulation of the mucosal immune response in the pathogenesis of IBD involves microbial factors, ${ }^{1}$ but may also include nanoparticles. In Western diets a high number ( $>10^{12}$ per day) of microparticles $(100-700 \mathrm{~nm}$ in diameter) are ingested daily. These have previously been considered immunologically inert, but accumulating evidence suggests that ingested microparticles are taken up by the intestinal mucosa and induce an immunological response. ${ }^{64}$ It was shown that conjugates of titanium oxide microparticles and lipopolysaccharide increase secretion of IL- $1 \beta$ in intestinal mucosal organ cultures. ${ }^{65}$ Moreover, a higher microparticleinduced release of IL- $1 \beta$ was seen in IBD explants. ${ }^{66}$ The microparticles seem to act as adjuvants, ${ }^{67}$ and may thereby aggravate inflammatory responses toward bacterial antigens in the intestinal lumen.

It has generally been believed that nanoparticles as well as Yersinia are only taken up at FAE, and recently a dysfunction of FAE leading to increased antigen exposure and a local immune response has been implicated in $\mathrm{CD} .{ }^{16,68,69}$ The present study shows that inv $+Y$. pseudotuberculosis can indeed induce a rapid increase in transport of nanoparticles in Caco-2 monolayers and human ileal tissues devoid of FAE. These results give further support to the notion that absorptive epithelial cells under the influence of external stimuli like enterobacteria can attain FAE-like properties, ie, start to sample antigens or exogenous, potentially proinflammatory particles from the intestinal lumen. This 'uncontrolled' sampling in villus epithelium represents a novel mechanism of barrier dysfunction that in the predisposed host may be involved in mucosal pathophysiology.

\section{ACKNOWLEDGEMENTS}

We are grateful to Dr Åke Forsberg, The Swedish National Research Establishment (FOF) and Umeå University, Umeå Sweden for providing the Yersinia pseudotuberculosis strains. National Network for Drug Development of the Swedish Foundation for Strategic Research, AstraZeneca R\&D Mölndal, Sweden (salary grant for PhD student), the Swedish Research Council-Medicine and the King Gustaf 80-Year Foundation.

\section{CONFLICT OF INTEREST}

None to declare.

1. Xavier RJ, Podolsky DK. Unravelling the pathogenesis of inflammatory bowel disease. Nature 2007:448:427-434.

2. Swidsinski A, Ladhoff A, Pernthaler A, et al. Mucosal flora in inflammatory bowel disease. Gastroenterology 2002;122:44-54.

3. Darfeuille-Michaud A, Boudeau J, Bulois $P$, et al. High prevalence of adherent-invasive Escherichia coli associated with ileal mucosa in Crohn's disease. Gastroenterology 2004;127:412-421.

4. Martin HM, Campbell BJ, Hart CA, et al. Enhanced Escherichia coli adherence and invasion in Crohn's disease and colon cancer. Gastroenterology 2004;127:80-93.
5. Hugot JP, Chamaillard M, Zouali $\mathrm{H}$, et al. Association of NOD2 leucinerich repeat variants with susceptibility to Crohn's disease. Nature 2001;411:599-603.

6. Ogura Y, Bonen DK, Inohara N, et al. A frameshift mutation in NOD2 associated with susceptibility to Crohn's disease. Nature 2001;411:603-606.

7. Rioux JD, Xavier RJ, Taylor KD, et al. Genome-wide association study identifies new susceptibility loci for Crohn disease and implicates autophagy in disease pathogenesis. Nat Genet 2007;39:596-604.

8. Hampe J, Franke A, Rosenstiel P, et al. A genome-wide association scan of nonsynonymous SNPs identifies a susceptibility variant for Crohn disease in ATG16L1. Nat Genet 2007;39:207-211.

9. Bjarnason I, MacPherson A, Hollander D. Intestinal permeability: an overview. Gastroenterology 1995;108:1566-1581.

10. Meddings JB. Review article: intestinal permeability in Crohn's disease. Aliment Pharmacol Ther 1997;11(Suppl 3):47-53; discussion -6.

11. Soderholm JD, Peterson $\mathrm{KH}$, Olaison $\mathrm{G}$, et al. Epithelial permeability to proteins in the noninflamed ileum of Crohn's disease? Gastroenterology 1999;117:65-72.

12. Soderholm JD, Streutker C, Yang PC, et al. Increased epithelial uptake of protein antigens in the ileum of Crohn's disease mediated by tumour necrosis factor alpha. Gut 2004;53:1817-1824.

13. Duchmann R, Kaiser I, Hermann E, et al. Tolerance exists towards resident intestinal flora but is broken in active inflammatory bowel disease (IBD). Clin Exp Immunol 1995;102:448-455.

14. Macpherson A, Khoo UY, Forgacs I, et al. Mucosal antibodies in inflammatory bowel disease are directed against intestinal bacteria. Gut 1996:38:365-375.

15. Sartor RB. Review article: role of the enteric microflora in the pathogenesis of intestinal inflammation and arthritis. Aliment Pharmacol Ther 1997;11(Suppl 3):17-22; discussion -3.

16. Hugot JP, Alberti C, Berrebi D, et al. Crohn's disease: the cold chain hypothesis. Lancet 2003;362:2012-2015.

17. Fiocchi C. Inflammatory bowel disease: etiology and pathogenesis. Gastroenterology 1998;115:182-205.

18. Buhner S, Buning C, Genschel J, et al. Genetic basis for increased intestinal permeability in families with Crohn's disease: role of CARD15 3020insC mutation? Gut 2006;55:342-347.

19. Wehkamp J, Harder J, Weichenthal M, et al. NOD2 (CARD15) mutations in Crohn's disease are associated with diminished mucosal alphadefensin expression. Gut 2004;53:1658-1664.

20. Rosenstiel P, Sina C, End C, et al. Regulation of DMBT1 via NOD2 and TLR4 in intestinal epithelial cells modulates bacterial recognition and invasion. J Immunol 2007;178:8203-8211.

21. Barnich N, Carvalho FA, Glasser AL, et al. CEACAM6 acts as a receptor for adherent-invasive $E$. coli, supporting ileal mucosa colonization in Crohn disease. J Clin Invest 2007;117:1566-1574.

22. Kallinowski F, Wassmer A, Hofmann MA, et al. Prevalence of enteropathogenic bacteria in surgically treated chronic inflammatory bowel disease. Hepatogastroenterology 1998;45:1552-1558.

23. Lamps LW, Madhusudhan KT, Havens JM, et al. Pathogenic Yersinia DNA is detected in bowel and mesenteric lymph nodes from patients with Crohn's disease. Am J Surg Pathol 2003;27:220-227.

24. Homewood R, Gibbons CP, Richards D, et al. lleitis due to Yersinia pseudotuberculosis in Crohn's disease. J Infect 2003;47:328-332.

25. Zippi M, Colaiacomo MC, Marcheggiano A, et al. Mesenteric adenitis caused by Yersinia pseudotubercolosis in a patient subsequently diagnosed with Crohn's disease of the terminal ileum. World J Gastroenterol 2006;12:3933-3935.

26. Eitel J, Dersch P. The YadA protein of Yersinia pseudotuberculosis mediates high-efficiency uptake into human cells under environmental conditions in which invasin is repressed. Infect Immun 2002;70:4880-4891.

27. Isberg RR, Voorhis DL, Falkow S. Identification of invasin: a protein that allows enteric bacteria to penetrate cultured mammalian cells. Cell 1987;50:769-778.

28. Schulte $R$, Kerneis $S$, Klinke $S$, et al. Translocation of Yersinia enterocolitica across reconstituted intestinal epithelial monolayers is triggered by Yersinia invasin binding to beta1 integrins apically expressed on M-like cells. Cell Microbiol 2000;2:173-185.

29. Isberg RR, Leong JM. Multiple beta 1 chain integrins are receptors for invasin, a protein that promotes bacterial penetration into mammalian cells. Cell 1990;60:861-871.

30. Tafazoli F, Holmstrom A, Forsberg A, et al. Apically exposed, tight junction- associated beta1-integrins allow binding and YopE-mediated 
perturbation of epithelial barriers by wild-type Yersinia bacteria. Infect Immun 2000;68:5335-5343.

31. Rescigno M, Urbano M, Valzasina B, et al. Dendritic cells express tight junction proteins and penetrate gut epithelial monolayers to sample bacteria. Nat Immunol 2001;2:361-367.

32. Artursson P, Karlsson J, Ocklind G, et al. Studying transport processes in absorptive epithelia. In: Shaw A (ed). Cell Models of Epithelial Tissues-A Practical Approach. IRL: Oxford, 1996, pp 111-133.

33. Keita AV, Gullberg E, Ericson AC, et al. Characterization of antigen and bacterial transport in the follicle-associated epithelium of human ileum. Lab Invest 2006;86:504-516.

34. Grass GM, Sweetana SA. In vitro measurement of gastrointestinal tissue permeability using a new diffusion cell. Pharm Res 1988;5:372-376.

35. Wallon $C$, Braaf $Y$, Wolving $M$, et al. Endoscopic biopsies in Ussing chambers evaluated for studies of macromolecular permeability in the human colon. Scand J Gastroenterol 2005;40:586-595.

36. Gullberg E, Keita AV, Salim SY, et al. Identification of cell adhesion molecules in the human follicle-associated epithelium that improve nanoparticle uptake into the Peyer's patches. J Pharmacol Exp Ther 2006;319:632-639.

37. Gullberg E, Leonard M, Karlsson J, et al. Expression of specific markers and particle transport in a new human intestinal M-cell model. Biochem Biophys Res Commun 2000;279:808-813.

38. Beaulieu JF. Differential expression of the VLA family of integrins along the crypt-villus axis in the human small intestine. J Cell Sci 1992;102(Part 3):427-436.

39. Hamzaoui N, Kerneis $\mathrm{S}$, Caliot $\mathrm{F}$, et al. Expression and distribution of beta 1 integrins in in vitro-induced $\mathrm{M}$ cells: implications for Yersinia adhesion to Peyer's patch epithelium. Cell Microbiol 2004;6:817-828.

40. Wang LH, Rothberg KG, Andersen RG. Mis-assembly of clathrin lattices on endosomes reveals a regulatory switch for coated pit formation. J Cell Biol 1993;123:1107-1117.

41. Christian AE, Page Haynes M, Phillips $C$, et al. Use of cyclodextrins for manipulating celular cholesterol content. J Lipid Res 1997;38:2264-2272.

42. Liu NQ, Lossinsky AS, Popik W, et al. Human immunodeficiency virus type 1 enters brain microvascular enothelia by macropinocytosis dependent on lipid rafts and the mitogen-activated protein kinase signaling pathway. J Virol 2002;76:6689-6700.

43. Wadia JS, Stan RV, Dowdy SF. Transducible TAT-HA fusogenic peptide enhances escape of TAT-fusion proteins after lipid raft macropinocytosis. Nat Med 2004;10:310-315.

44. Nakase I, Niwa M, Takeuchi T, et al. Cellular uptake of arginine-rich peptides: roles for macropinocytosis and actin rearrangement. Mol Ther 2004;10:1011-1022.

45. Kerneis S, Bogdanova A, Kraehenbuhl JP, et al. Conversion by Peyer's patch lymphocytes of human enterocytes into $M$ cells that transport bacteria. Science 1997;277:949-952.

46. Borghesi C, Taussig MJ, Nicoletti C. Rapid appearance of M cells after microbial challenge is restricted at the periphery of the follicleassociated epithelium of Peyer's patch. Lab Invest 1999;79:1393-1401.

47. Meynell HM, Thomas NW, James PS, et al. Up-regulation of microsphere transport across the follicle-associated epithelium of Peyer's patch by exposure to Streptococcus pneumoniae R36a. FASEB J 1999;13:611-619.

48. Lyons $\mathrm{S}$, Wang L, Casanova JE, et al. Salmonella typhimurium trancytoses flagellin via an SP12-mediated vesicular transport pathway. J Cell Sci 2004;117:5771-5780.

49. Kerr JR. Cell adhesion molecules in the pathogenesis of and host defence against microbial infection. Mol Pathol 1999:52:220-230.
50. Cossart P, Sansonetti PJ. Bacterial invasion: the paradigms of enteroinvasive pathogens. Science 2004;304:242-248.

51. Elsaraj SM, Bhullar RP. Regulation of platelet Rac1 and Cdc42 activation through interaction with calmodulin. Biochim Biophys Acta 2008;1783:770-778.

52. Ridley AJ. Rho proteins: linking signaling with membrane trafficking. Traffic 2001;2:303-310.

53. West MA, Prescott AR, Eskelinen EL, et al. Rac is required for constitutive macropinocytosis by dendritic cells but does not control its downregulation. Curr Biol 2000;10:839-848.

54. Rothberg KG, Ying YS, Kamen BA, et al. Cholesterol controls the clustring of the glycophospholipid-anchored membrane receptor for 5-methyltetrahydrofolate. J Cell Biol 1990;111:2931-2938.

55. Grimmer S, van Deurs B, Sandvig K, et al. Membrane ruffling and macropinocytosis in A431 cells require cholesterol. J Cell Sci 2002;115:2953-2962.

56. Jones AT. Macropinocytosis: searching for endocytotic identity and a role in the uptake of cell penetrating peptides. J Cell Mol Med 2007;11:670-684.

57. Kleyman TR, Cragoe Jr EJ. Amiloride and its analogs as tools in the study of ion transport. J Membr Biol 1988;105:1-21.

58. Lagana A, Vadnais J, Le PU, et al. Regulation of the formation of tumor cell pseudopodia by the $\mathrm{Na}(+) / \mathrm{H}(+)$ exchanger NHE1. J Cell Sci 2000;113:3649-3662.

59. West MA, Bretscher MS, Watts C. Distinct endocytotic pathways in epidermal growth factor-stimulated human carcinoma A431 cells. J Cell Biol 1989;109:2731-2739.

60. Fallman M, Gustavsson A. Cellular mechanisms of bacterial internalization counteracted by Yersinia. Int Rev Cytol 2005;246: 135-188.

61. Von Pawel-Rammingen U, Telepnev MV, Schmidt G, et al. GAP activity of the Yersinia YopE cytotoxin specifically targets the Rho pathway: a mechanism for disruption of actin microfilament structure. Mol Microbiol 2000;36:737-748.

62. Grassl GA, Bohn E, Muller Y, et al. Interaction of Yersinia enterocolitica with epithelial cells: invasin beyond invasion. Int J Med Microbiol 2003;293:41-54

63. Cavalli V, Vilbois F, Corti M, et al. The stress-induced MAP kinase p38 regulates endocytic trafficking via the GDI:Rab5 complex. Mol Cell 2001;7:421-432.

64. Powell JJ, Thoree V, Pele LC. Dietary microparticles and their impact on tolerance and immune responsiveness of the gastrointestinal tract. $\mathrm{Br} J$ Nutr 2007;98(Suppl 1):S59-S63.

65. Powell JJ, Harvey RS, Ashwood P, et al. Immune potentiation of ultrafine dietary particles in normal subjects and patients with inflammatory bowel disease. J Autoimmun 2000;14:99-105.

66. Evans SM, Ashwood P, Warley A, et al. The role of dietary microparticles and calcium in apoptosis and interleukin-1 beta release of intestinal macrophages. Gastroenterology 2002;123:1543-1553.

67. Butler M, Boyle JJ, Powell JJ, et al. Dietary microparticles implicated in Crohn's disease can impair macrophage phagocytic activity and act as adjuvants in the presence of bacterial stimuli. Inflamm Res 2007;56:353-361.

68. Keita $\AA V$, Salim SY, Jiang T, et al. Increased uptake of non-pathogenic E. coli via follicle-associated epithelium and dendritic cells in ileal Crohn's disease. J Pathol 2008;215:135-144.

69. Barreau F, Meinzer U, Chareyre F, et al. CARD15/NOD2 is required for Peyer's patches homeostasis in mice. PLoS ONE 2007; 2:e523. 